\title{
Antibacterial properties of the sperm-binding proteins and peptides of human epididymis 2 (HE2) family; salt sensitivity, structural dependence and their interaction with outer and cytoplasmic membranes of Escherichia coli
}

\author{
Suresh YENUGU*, Katherine G. HAMIL*, Charles E. BIRSE $\dagger$, Steven M. RUBEN†, Frank S. FRENCH* and Susan H. HALL*1 \\ *Laboratories for Reproductive Biology, Department of Pediatrics, University of North Carolina, Chapel Hill, NC 27599-7500, U.S.A., and † Human Genome Sciences Inc., \\ 9410 Key West Avenue, Rockville, MD 20850-3338, U.S.A.
}

\begin{abstract}
During passage through the epididymis, sperm interact with secreted epididymal proteins that promote maturation, including the acquisition of motility and fertilization competence. Viewed previously as distinct from sperm maturation, host defence capabilities are now recognized functions of the human epididymis 2 (HE2) family of sperm-binding proteins. We analysed the potent dose and time-dependent bactericidal activity of recombinant HE $2 \alpha$, HE $2 \beta 1$ and HE2 $\beta 2$ and found that the full-length proteins $(10 \mu \mathrm{g} / \mathrm{ml}$ or $\sim 1 \mu \mathrm{M})$ caused more than a $50 \%$ decrease in Escherichia coli colony forming units within $15 \mathrm{~min}$. By contrast, human $\beta$-defensin- 1 , at a similar concentration, required more than $90 \mathrm{~min}$ to exhibit similar antibacterial activity. The epididymis-specific lipocalin, LCN6, failed to kill bacteria. Higher concentrations $(25-100 \mu \mathrm{g} / \mathrm{ml})$ of HE2 proteins and a longer duration of treatment resulted in near total inhibition of bacterial growth. The C-terminal peptides of $\operatorname{HE} 2 \alpha, \operatorname{HE} \beta 1$ and $\mathrm{HE} \beta 2$ proteins exhibited antibacterial activity similar to their full-
\end{abstract}

length counterparts, indicating that the antibacterial activity of HE2 proteins resides in these C-terminal regions. Antibacterial activities of HE2 proteins and peptides were slightly inhibited by $\mathrm{NaCl}$ concentrations of up to $150 \mathrm{mM}$, while human $\beta$-defensin1 activity was nearly eliminated. Reduction and alkylation of disulphide bonds in HE2 proteins and their C-terminal peptides abolished their antibacterial activity. Consistent with the ability to kill bacteria, full-length HE2 proteins and $\mathrm{C}$-terminal peptides caused rapid dose-dependent permeabilization of outer and cytoplasmic E. coli membranes. A much longer exposure time was required for human $\beta$-defensin-1-mediated permeabilization of membranes, suggesting a possible difference in mode of action compared with the HE2 antibacterial peptides.

Key words: antibacterial activity, defensin, fertility, host defence, human epididymis 2 (HE2), sperm-binding protein.

\section{INTRODUCTION}

Antimicrobial proteins and peptides are vital components of the innate immune systems that protect plants and animals against invading pathogens. In animals these proteins are involved in a variety of pathophysiological conditions [1-4]. Host defence proteins of the male reproductive tract have become a subject of investigation [5], in part because of their potential importance in sexually transmitted diseases. Antimicrobial proteins reported in the male tract include the cathelicidins [6], human cationic antimicrobial protein (hCAP)-18 [7,8], bovine seminalplasmin $[9,10]$, lactoferrin [11], the protease inhibitors cystatin $3[12,13]$, cystatin $11[14]$ and secretory leukocyte protease inhibitor $[15,16]$, as well as members of the $\beta$-defensin family [17-20] and Bin $1 \mathrm{~b}$ [21]. Of these, hCAP-18 [7], lactoferrin [11] and cystatin 11 [14] bind the surface of sperm, as do the human epididymis 2 (HE2), proteins $[22,23]$. Sperm acquire these proteins during passage through the epididymis, where they develop mature functions including forward motility and the ability to fertilize the egg.

The HE2 gene (sperm antigen 11), encoding human homologues of the rat Bin1b [24] and chimpanzee epididymal protein $2[25,26]$, is located on chromosome 8p23 within the $\beta$-defensin gene cluster. The HE2 gene produces a large family of alternatively spliced transcripts [23] derived from at least 8 exons [27]. The exons are variously assembled to encode a series of isoforms containing at least 8 different $\mathrm{C}$-terminal peptides. The three isoforms, i.e. HE $2 \alpha$, HE2 $\beta 1$, and HE $2 \beta 2$ contain identical signal peptides and proregions joined to different C-terminal peptides (Figure 1). The peptides conserve characteristic basic and hydrophobic amino acids and stabilizing disulphide bonds similar to those of the $\beta$-defensin family [28]. Evidence suggests that they are cleaved from the proregion by a furin-like proprotein convertase [29]. $\beta$-Defensins are similarly synthesized as 6090 amino acid precursors, which are digested by an endogenous protease to release the active peptides.

Defensins exhibit broad-spectrum antimicrobial activity against viruses [30,31], fungi, Gram-positive bacteria [32] and Gramnegative bacteria [33]. Gram-negative bacterial cytoplasm is enclosed within two membranes separated by a periplasmic space. Negatively charged phospholipids and lipopolysaccharides of bacterial outer membranes bind the positively charged defensins, whereas there is no similar charge interaction with the plasma membranes of animal cells, which are composed primarily of neutral lipids [34]. Defensin-induced permeabilization of bacterial membranes is associated with the cessation of DNA, RNA and protein synthesis [35] and appears to be the lethal event resulting in bacterial death [35].

The existence of the HE2 C-terminal peptides in human epididymal epithelium, fluid and ejaculate was recently demonstrated [29]. Independent prediction of their existence is provided

Abbreviations used: HE2, human epididymis 2; hCAP, human cationic antimicrobial protein; LCN, lipocalin; CFU, colony forming units; BME, $\beta$-mercaptoethanol; NPN, N-phenyl-1-naphthylamine; diSC3-5, 3,5-dipropylthiadicarbocyanine iodide.

To whom correspondence should be addressed (e-mail shh@med.unc.edu). 
DEFB1

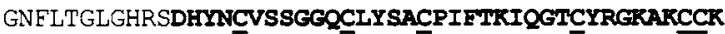

DEFB2

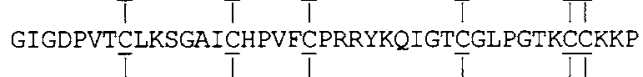

HE2 31 RHVNHSATEALGELRERAPGQGTNGFQLLRHAVKRDLLPPRT PPYQGDVPPGIRNTICFMOOGICRLFECHSGEKKRDICSDPNNRCCVSNTDGEGKGKPIMDGRSGI

HE2ß2 RHVNHSATEALGELRERAPGQGTNGEQLLRHAVKRDLLPPRTPPYQGOVPPGIRNTICEMOOGICRLFECHSGTGOOHRQRGG

HE2 $\alpha$ RHVNHSATEALGELRERAPGQGTNGFQLLRHAVKRDLLPPRT PPYQVHISHREARGPSFRICVGFLGPRWARGCSTGN

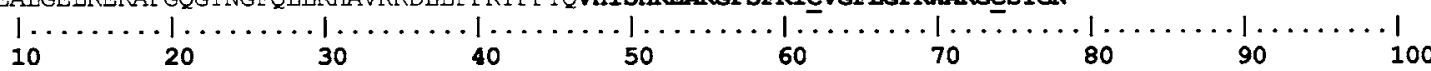

Figure 1 Amino acid sequences of human $\beta$-defensin-1, human $\beta$-defensin-2 and HE2 isoforms

Amino acid sequences shown in bold correspond to the C-terminal peptides used in the antibacterial assays in this study. The cysteines are underlined. The underlined amino acid sequence in HE2 $\beta 1$ was used for 3-dimensional structural analysis.

by the cDNAs for the B isoform (accession number AF466346) and the $\mathrm{E}$ isoform (accession number AF466348). These encode the C-terminal peptides of $\mathrm{HE} 2 \alpha$ and $\mathrm{HE} 2 \beta 1$, respectively, bearing only two additional $\mathrm{N}$-terminal amino acid residues instead of the 46 amino acid proregion.

HE2 proteins and peptides are cationic with pIs ranging from 7-12 and, thus, may exhibit antimicrobial properties similar to $\beta$-defensins, and other cationic antimicrobial proteins and peptides. Indeed, antimicrobial activity of human seminal-plasmacationic extracts was reported [20]. The antibacterial activities of synthetic HE $2 \alpha$ and HE $2 \beta 1$ peptides have been reported recently [29], however, the mechanisms involved are not well understood. Furthermore, little is known about the mechanism of antibacterial action of the earlier reported antimicrobial proteins in the reproductive tissues [5]. Here we analyse the antibacterial activities of $\operatorname{HE} 2 \alpha$, $\operatorname{HE} 2 \beta 1$, and $\operatorname{HE} 2 \beta 2$, mature proteins and their $\mathrm{C}$-terminal peptides. Structural similarities between $\beta$-defensins and HE2 proteins prompted us to determine whether permeabilization of outer and inner E. coli membranes is an event in HE2-mediated bacterial cell death. Our results demonstrate that HE2 proteins and peptides exhibit structure-dependent antibacterial activity, which is salt-tolerant and involves a rapid outer and inner membrane permeabilization.

\section{EXPERIMENTAL PROCEDURES}

\section{Three-dimensional structural analysis of HE2 $\beta 1$}

The bioinbgu server (http://www.cs.bgu.ac.il/ bioinbgu/) [36], was used to thread the sequence of $\mathrm{HE} 2 \beta 1 \mathrm{C}$-terminal peptide from Gly-52 to Asn-91 on to the structure of human $\beta$-defensin2, 1FD3.pdb in the Protein Data Bank [37]. A model of HE2 $\beta 1$ peptide was built using the Modeler module of the Insight II molecular modelling system from Accelrys Inc. (San Diego, CA, U.S.A. and http:// www.accelrys.com). The figure was created using SPOCK [38] in the Structural BioInformatics Core Facility (University of North Carolina at Chapel Hill, NC, U.S.A.) under the direction of Dr Brenda Temple.

\section{Recombinant protein production and peptide synthesis}

Recombinant proteins were prepared as described previously [23]. In brief, E. coli strain M15 (pREP4) was transformed with pQE30 vector (Qiagen, Valencia, CA, U.S.A.) containing HE2 $\alpha$, HE2 $\beta 1$, HE2 $\beta 2$ or lipocalin (LCN)6 cDNA according to the Qiagen protocol. Fusion-protein expression was induced with $1 \mathrm{mM}$ isopropyl $\beta$-D-thiogalactoside for $2 \mathrm{~h}$ at $37^{\circ} \mathrm{C}$. Bacterial lysate, incubated with $\mathrm{Ni}^{2+}$-nitrilotriacetate-agarose (Qiagen) was transferred to acolumn, washed and eluted according to the manufacturer's recommendations. Fractions were analysed on 10-20\% gradient Tris/Tricine gels (InVitrogen, Carlsbad, CA, U.S.A.) and stained with Coomassie Blue G250. Fractions containing purified protein were pooled and dialysed against $10 \mathrm{mM}$ sodium phosphate buffer ( $\mathrm{pH}$ 7.4) to remove urea. The His tag was removed using the Tagzyme system (Qiagen) according to the manufacturer's protocol. Tagzyme removed the entire tag leaving the HE2 proteins intact. The recombinant HE2 proteins and HE $2 \beta 1$ peptide contained the following additional amino acid residues at their N-termini (MRGSHHHHHHGS), due to the construction of vector $\mathrm{H}_{2} \mathrm{~N}$-MRGSHHHHHHGS-COOH.

$\mathrm{HE} 2 \alpha$ and HE2 $\beta 2 \mathrm{C}$-terminal peptides without the His tag were synthesized at the Peptide Synthesis Facility (University of North Carolina, Chapel Hill, NC, U.S.A.) by standard fluoren9-ylmethoxycarbonyl ('Fmoc') solid-phase procedures using a Rainin symphony multiple peptide synthesizer (Rainin Instrument, Woburn, MA, U.S.A.). The purified peptides eluted as single peaks upon reverse phase HPLC and were further demonstrated to have their corresponding molecular mass by matrix-assisted laser-desorption ionization-time-of-flight ('MALDI-TOF') mass spectrometry. HE2 $\beta 1$ C-terminal peptide was expressed in $E$. coli and purified as described for the full-length proteins. The control peptides c-JUN (DPYRGLKGPGARGPGPEGGC) and CREB (KILNDLSSDAPGVPA) were synthesized at the Peptide Synthesis Facility.

\section{Reduction and alkylation}

HE2 proteins and peptides were reduced and alkylated according to the protocol described at Massachusetts Institute of Technology Center for Cancer Research, Howard Hughes Medical Institute (MITCCR-HHMI) biopolymers laboratory web site (http://web.mit.edu/biopolymers/www/protein_sequencing. html). Briefly, the protein or peptide $(10 \mu \mathrm{g})$ in $0.3 \mathrm{M} \mathrm{Tris} / \mathrm{HCl}$ buffer ( $\mathrm{pH} 8.0$ ) containing $8 \mathrm{M}$ urea as a denaturant was treated with $\beta$-mercaptoethanol (BME; Sigma, St. Louis, MO, U.S.A.) under nitrogen for $4 \mathrm{~h}$ at $37^{\circ} \mathrm{C}$ to reduce the disulphide bonds. The reduced protein was alkylated immediately by adding iodoacetamide (Sigma) in a $20 \%$ molar excess over the total number of thiols, and incubated for $1 \mathrm{~h}$ at $37^{\circ} \mathrm{C}$ in the dark, under nitrogen. The reaction was terminated by freezing the samples immediately in $\mathrm{a}-80^{\circ} \mathrm{C}$ freezer, followed by dialysis against $10 \mathrm{mM}$ sodium phosphate buffer $(\mathrm{pH} 7.4)$ to remove excess BME and iodoacetamide. A control reaction, containing sodium phosphate buffer without protein, was treated similarly to determine whether residual BME and iodoacetamide affected bacterial growth in the assays. 


\section{Antibacterial assays}

A colony forming units (CFU) assay was employed to test the antibacterial activity as described previously [40]. Briefly, overnight cultures of $E$. coli XL-1 blue (Stratagene, La Jolla, CA, U.S.A.) were allowed to grow to mid-log phase $\left(A_{600}=0.4\right.$ $0.5)$ and diluted with $10 \mathrm{mM}$ sodium phosphate buffer ( $\mathrm{pH} 7.4)$. Approximately $2 \times 10^{6} \mathrm{CFU} / \mathrm{ml}$ of bacteria were incubated at $37^{\circ} \mathrm{C}$ with $10-100 \mu \mathrm{g} / \mathrm{ml}$ of the proteins or peptides, and aliquots of the assay mixture were taken at 5, 10, 15 and $30 \mathrm{~min}$ after the start of incubation. After incubation, the assay mixtures were serially diluted with $10 \mathrm{mM}$ sodium phosphate buffer ( $\mathrm{pH} 7.4$ ) and $100 \mu$ l of each was spread on a Luria-Bertani agar plate and incubated at $37^{\circ} \mathrm{C}$ overnight to allow full colony development. The resulting colonies were hand counted. Human $\beta$-defensin1 (Peptide Institute Inc., Osaka, Japan) was used as a positive control. BSA (Sigma) was used as a negative control. To test the effect of high salt on antibacterial activity, E. coli were incubated for $2 \mathrm{~h}$ with the protein or peptide in $10 \mathrm{mM}$ sodium phosphate buffer ( $\mathrm{pH}$ 7.4) containing varying concentrations of $\mathrm{NaCl}$ ranging from 25 to $300 \mathrm{mM}$. Following incubation, the assay mixtures were diluted with $10 \mathrm{mM}$ sodium phosphate buffer ( $\mathrm{pH} 7.4)$, without added salt, and spread on Luria-Bertani agar plates as described above. Antibacterial activity expressed as percentage survival was calculated using the following formula: \% survival $=$ (number of colonies surviving after treatment with the antibacterial peptide/number of colonies surviving without the antibacterial peptide) $\times 100$.

\section{Outer-membrane-permeability assay}

The ability of epididymal proteins and their peptides to permeabilize the outer membrane of $E$. coli was assessed by the $N$-phenyl-1-naphthylamine (NPN; Molecular Probes, Eugene, OR, U.S.A.) assay of Loh et al. [41]. An overnight culture of $E$. coli was grown to mid-log phase, washed twice with $5 \mathrm{mM}$ Hepes buffer ( $\mathrm{pH} 7.4$ ) containing $5 \mathrm{mM}$ glucose, and resuspended in the same buffer containing $10 \mu \mathrm{M}$ NPN up to an $A_{600}$ of 0.25 . To a $60 \mu \mathrm{l}$ aliquot of this suspension, varying concentrations of the protein or peptide were added. Fluorescence was monitored using an Aminco SLM 8100 fluorescence spectrophotometer (SLM Instruments Inc., Urbana, IL, U.S.A.) with the excitation monochromator set at $350 \mathrm{~nm}$ and the emission set at $420 \mathrm{~nm}$.

\section{Inner-membrane-permeability assay}

Permeabilization of the cytoplasmic membrane was determined using the cyanine dye 3,5-dipropylthiadicarbocyanine iodide (diSC3-5; Molecular Probes, Eugene, OR, U.S.A.) by the method of $\mathrm{Wu}$ et al. [42]. Mid-log phase E. coli were washed twice with $5 \mathrm{mM}$ Hepes buffer (pH 7.4) containing $5 \mathrm{mM}$ glucose, and resuspended in the same buffer up to an $A_{600}$ of 0.05 . The cell suspension was incubated with $0.4 \mu \mathrm{M}$ diSC3-5 until the uptake was maximal, as indicated by a stable reduction in fluorescence. To this suspension varying concentrations of the protein or peptide were added and the fluorescence was monitored in an Aminco SLM 8100 fluorescence spectrophotometer with the excitation monochromator set at $622 \mathrm{~nm}$ and the emission at $670 \mathrm{~nm}$.

\section{Haemolysis assay}

Haemolytic activity of epididymal proteins and their peptides was determined as described previously [43]. Erythrocytes from heparinized rat blood were washed three times with $0.9 \%$ saline and resuspended to a concentration of $5 \%$ in saline. Erythrocytes were treated with different concentrations of the proteins or peptides $(10 \mu \mathrm{g} / \mathrm{ml}$ to $100 \mu \mathrm{g} / \mathrm{ml})$ in a 96 -well plate and incubated at $37{ }^{\circ} \mathrm{C}$ for $1 \mathrm{~h}$. The plate was centrifuged at $1000 \mathrm{~g}$ for $10 \mathrm{~min}$ and supernatants were transferred to a fresh plate. Absorbance (at $560 \mathrm{~nm}$ ) of saline and $1 \%$ Triton X-100-treated erythrocytes served as $0 \%$ and $100 \%$ haemolysis controls, respectively.

\section{RESULTS}

\section{Three-dimensional structural analysis of HE2 $\beta 1$}

The predicted three-dimensional structure of defensin-like HE2 $\beta 1$ peptide having the 6-cysteine array (Figure 2) was modelled, based on the crystal structure of human $\beta$-defensin2 [44]. HE2 $\beta 1 \mathrm{C}$-terminal peptide is predicted to form a short $\mathrm{N}$-terminal amphipathic $\alpha$-helix and a three-stranded twisted $\beta$-sheet, stabilized by three disulphide bridges. Like defensins,
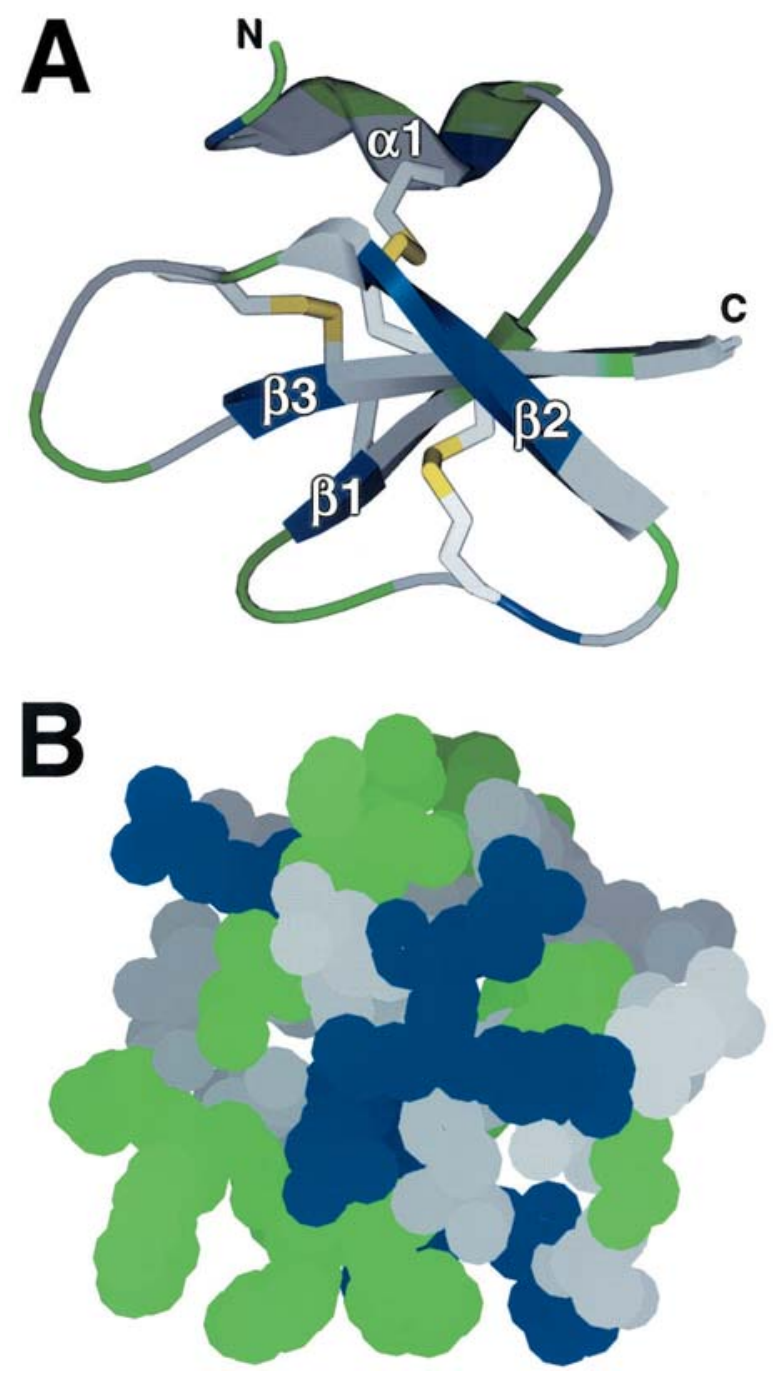

Figure 2 HE2 $\beta 1$ peptide model

(A) Ribbon model showing the architecture of $\alpha$-helix and $3 \beta$-strands (B) Space-filled model. Basic amino acids are blue and hydrophobic amino acids are green. $\mathrm{N}$ indicates the $\mathrm{N}$-terminal Gly-52 and $\mathrm{C}$ indicates the $\mathrm{C}$-terminal Asn-91. The 3 disulphide bonds are indicated in yellow. 

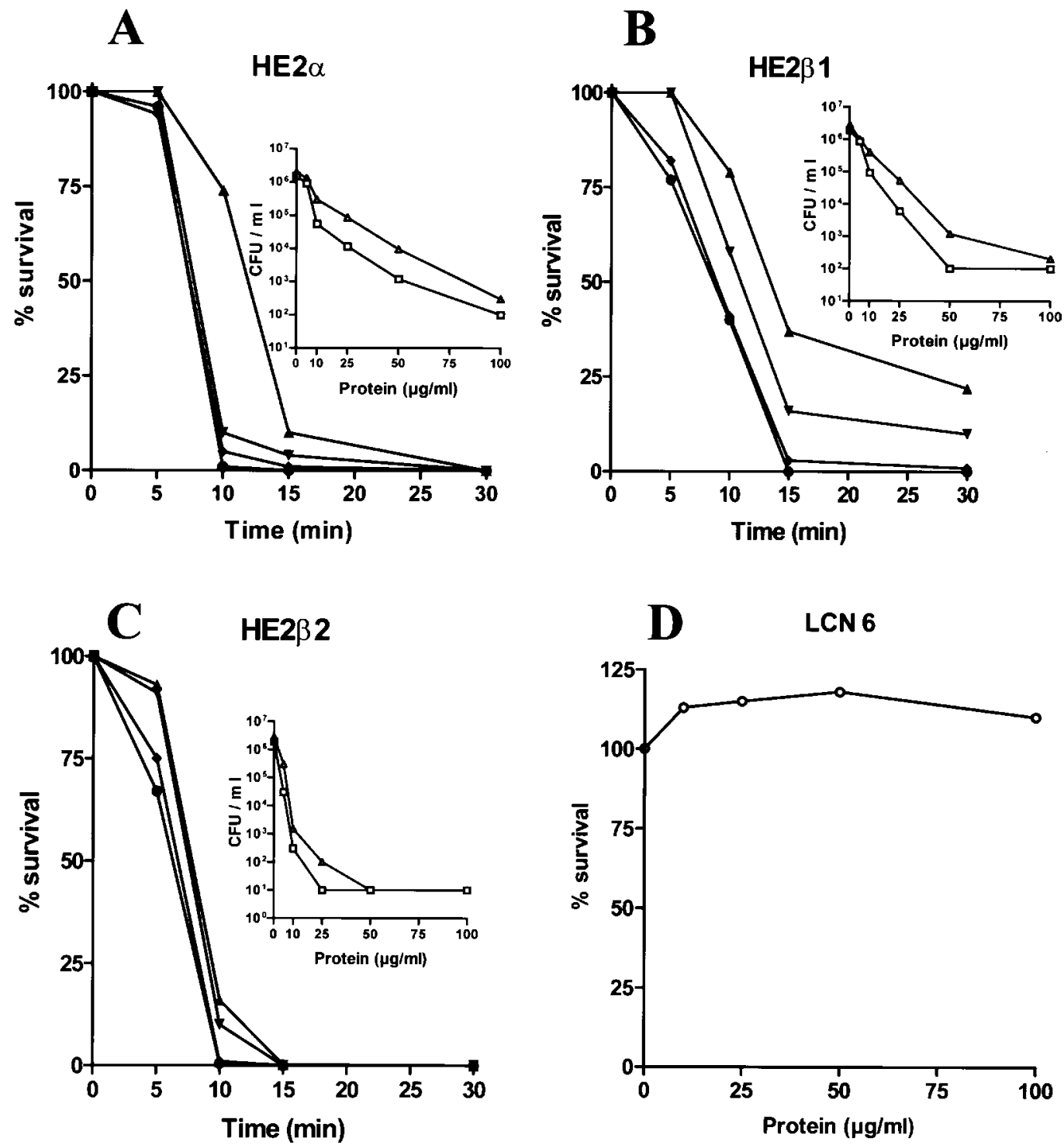

Figure 3 Kinetics of $E$. coli-killing by HE2 proteins

E. coli were incubated for 5-30 min with $10 \mu \mathrm{g} / \mathrm{ml}(\mathbf{\Lambda}), 25 \mu \mathrm{g} / \mathrm{ml}(\mathbf{\nabla}), 50 \mu \mathrm{g} / \mathrm{ml}(\bullet)$, and $100 \mu \mathrm{g} / \mathrm{ml}(\mathbf{\bullet})$ protein. (A) HE2 $\alpha$, (B) HE2 $\beta 1$ and (C) HE2 $\beta 2$. Insets in panels A, B and C show the antibacterial activity of HE2 proteins with $(\square)$ and without $(\triangle)$ His-tag incubated with $E$. coli for 15 min. (D) Antibacterial activity of LCN6 after $2 \mathrm{~h}$ incubation.

HE $2 \beta 1$ peptide tertiary structure presents regional concentrations of basic and hydrophobic amino acids that may be involved in mediating bacterial killing (reviewed in [45]).

\section{Antibacterial activity}

To analyse $\operatorname{HE} 2 \alpha$, HE2 $\beta 1$, and HE $2 \beta 2$ antibacterial activity, a 10 -fold concentration range of each protein was incubated with E. coli for 5-30 min (Figures 3A-3C). Approx. 10\% of bacteria survived after incubation with $25 \mu \mathrm{g} / \mathrm{ml}(2.8 \mu \mathrm{M}) \mathrm{HE} 2 \alpha$ for 10 minutes. Similar results were seen after incubation with $10 \mu \mathrm{g} / \mathrm{ml}(1.07 \mu \mathrm{M}) \mathrm{HE} 2 \beta 2$. In the case of HE2 $\beta 1,50 \mu \mathrm{g} / \mathrm{ml}$ $(4.1 \mu \mathrm{M})$ for 15 minutes was required to reduce bacterial survival to $10 \%$. The inset (Figures 3A-3C) shows the antibacterial activity of HE2 proteins with and without the His tag. The antibacterial potencies of the His tag removed HE2 proteins were similar to those of their His-tagged counterparts. The control proteins, recombinant LCN6 (Figure 3D) and BSA (results not shown) showed no detectable antibacterial activity when incubated for $2 \mathrm{~h}$ at concentrations up to $100 \mu \mathrm{g} / \mathrm{ml}$.

Similar to the full-length proteins, the HE2 $\alpha, \operatorname{HE} 2 \beta 1$, and HE2 $\beta 2$ C-terminal peptides exhibited potent dose and timedependent antibacterial activity against $E$. coli (Figures 4A-4C). A $90 \%$ reduction in CFU was observed after incubation with $50 \mu \mathrm{g} / \mathrm{ml}(14.2 \mu \mathrm{M}) \mathrm{HE} 2 \alpha$ peptide for $10 \mathrm{~min}$, whereas the HE2 $\beta 1$ and HE2 $\beta 2$ peptides were more effective. HE2 $\beta 1$ peptide caused a $90 \%$ reduction in CFU after incubation for $10 \mathrm{~min}$ at $25 \mu \mathrm{g} / \mathrm{ml}(2.65 \mu \mathrm{M})$ and the HE2 $\beta 2$ peptide reduced survival to zero after 10 minutes incubation at all concentrations tested. Thus, the potencies of HE $2 \beta 1$ and HE2 $\beta 2$ peptides were similar to the full-length proteins, consistent with the prediction that the activity resides in the $\mathrm{C}$-terminal peptides. The lower activity of HE2 $\alpha$ $\mathrm{C}$-terminal peptide compared with the full-length protein was unexpected and may indicate a stabilizing or protective effect of the pro-region on the HE $2 \alpha$ peptide. Removal of the His tag from 

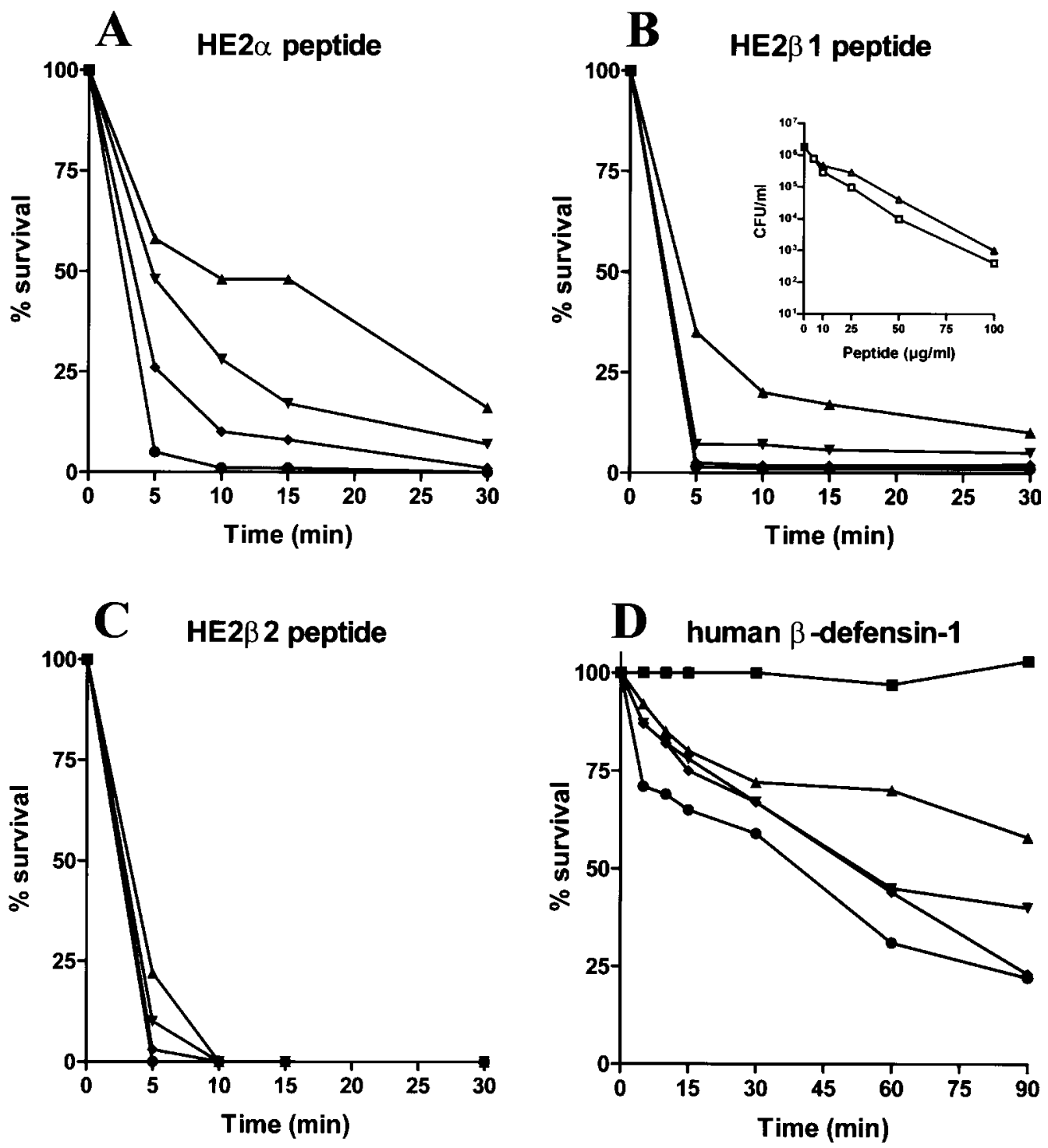

Figure 4 Kinetics of $E$. coli-killing by HE2 C-terminal peptides and human $\beta$-defensin-1

E. coli were incubated for 5-30 min with $10 \mu \mathrm{g} / \mathrm{ml}(\mathbf{\Lambda}), 25 \mu \mathrm{g} / \mathrm{ml}(\mathbf{\nabla}), 50 \mu \mathrm{g} / \mathrm{ml}(\bullet)$, and $100 \mu \mathrm{g} / \mathrm{ml}(\bullet)$ peptide, (A) HE2 $\alpha$ peptide, (B) HE2 $\beta 1$ peptide and (C) HE2 $\beta 2$ peptide. The inset in panel $\mathbf{B}$ shows the antibacterial activity of HE2 $\beta 1$ peptide with $(\square)$, and without $(\triangle)$ His-tag incubated with $E$. coli for 15 min. (D) Antibacterial activity of human $\beta$-defensin-1. E. coli were incubated with human $\beta$-defensin-1 for $1-3 \mathrm{~h}$ with $0 \mu \mathrm{g} / \mathrm{ml}(\boldsymbol{\square}), 10 \mu \mathrm{g} / \mathrm{ml}(\mathbf{\Lambda}), 25 \mu \mathrm{g} / \mathrm{ml}(\mathbf{\nabla}), 50 \mu \mathrm{g} / \mathrm{ml}(\bullet)$, and $100 \mu \mathrm{g} / \mathrm{ml}(\boldsymbol{\bullet})$.

the recombinant HE2 $\beta 1$ peptide slightly reduced its antibacterial activity (Figure 4B, inset). Human $\beta$-defensin- 1 antibacterial activity was much slower acting than the HE2 peptides in these assays. After $90 \mathrm{~min}$ exposure to human $\beta$-defensin- 1 $(100 \mu \mathrm{g} / \mathrm{ml}), 20 \%$ of the bacteria survived (Figure 4D). Not until after 180 min exposure were CFU reduced below the limits of detection (results not shown). Control synthetic peptides of transcription factors CREB and c-JUN did not affect bacterial survival and growth, even after $2 \mathrm{~h}$ exposure to $100 \mu \mathrm{g} / \mathrm{ml}$ (results not shown).

The conserved arrangement of the six cysteines in $\beta$-defensins supports the concept that specific disulphide bridges are required for full antibacterial function. Recent studies showed that antibacterial activity was preserved when at least one disulphide bond was present in each active peptide [46]. To determine whether HE2 disulphide bonds are essential for antibacterial activity, disulphide bonds in the three proteins and C-terminal peptides were reduced and alkylated. These denatured full- length proteins and peptides completely failed to kill E. coli even when incubated for $2 \mathrm{~h}$ at a concentration of $100 \mu \mathrm{g} / \mathrm{ml}$ (Figure 5) indicating the requirement for disulphide-bondconstrained tertiary structure for the antibacterial activity.

$\beta$-Defensins are reported to lose antibacterial activity in highsalt conditions possibly due to interference with electrostatic interactions with bacterial surfaces $[1,40,47,48]$. Whether HE2 peptides were similarly affected by ambient salt concentrations was determined by incubating full-length proteins and C-terminal peptides for $2 \mathrm{~h}$ with $E$. coli in $0-300 \mathrm{mM} \mathrm{NaCl}$. The presence of $\mathrm{NaCl}$ alone, without peptides, increased bacterial growth substantially. In the absence of $\mathrm{NaCl}, 0-3 \%$ of bacteria survived in the presence of HE2 proteins (Figure 6A) or peptides (Figure 6B). In the presence of increasing salt concentrations, bacterial survival increased in the presence of HE2 proteins and peptides. However, substantial antibacterial activity was retained in up to $150 \mathrm{mM} \mathrm{NaCl}$. In $150 \mathrm{mM} \mathrm{NaCl}, \mathrm{HE} 2 \beta 1$ activity was the most salt-sensitive of the three HE2 isoforms with $25 \%$ 


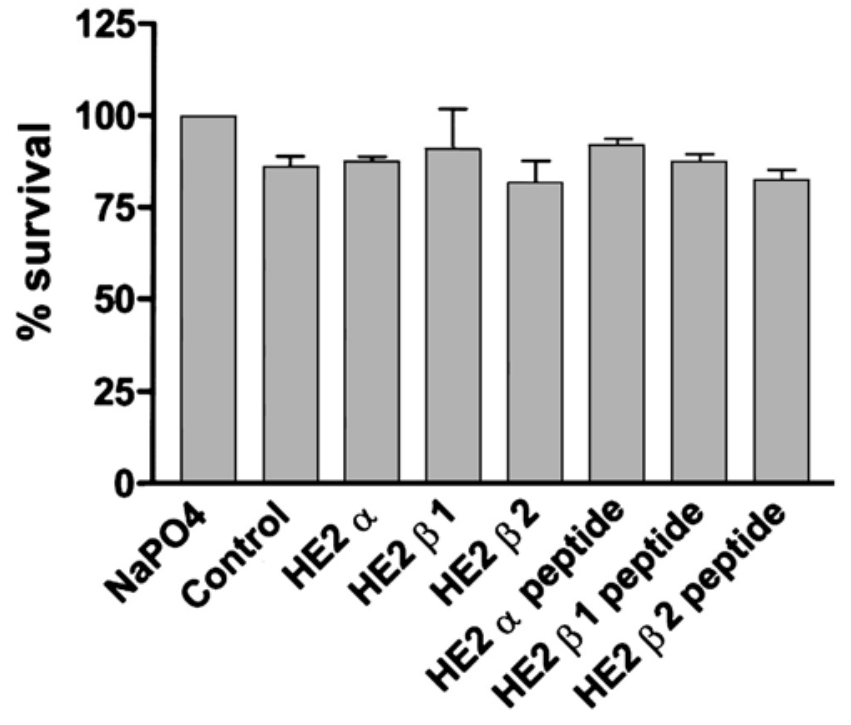

Figure 5 Effect of disulphide bond reduction and alkylation on the antibacterial activity of HE2 proteins and peptides

E. coli were incubated for $2 \mathrm{~h}$ with $100 \mu \mathrm{g} / \mathrm{ml}$ disulphide-bond reduced protein or peptide. $\mathrm{NaPO}_{4}$ indicates $E$. coli incubated with only $10 \mathrm{mM}$ sodium phosphate buffer $(\mathrm{pH}$ 7.4) without any added protein or peptide. Control indicates sodium phosphate buffer without protein was given the same treatment as alkylating proteins and dialysed to determine whether residual BME and iodoacetamide affected bacterial growth in the assays.

bacterial survival increasing to $30 \%$ survival in $300 \mathrm{mM}$ salt. $\mathrm{HE} 2 \alpha$ maintained $10 \%$ bacterial survival at $150 \mathrm{mM} \mathrm{NaCl}$ and $20 \%$ survival at $300 \mathrm{mM} \mathrm{NaCl}$. HE2 $\beta 2$ was the most salt-tolerant, permitting less than $4 \%$ bacterial survival in $150 \mathrm{mM} \mathrm{NaCl}$ and $10 \%$ survival in $300 \mathrm{mM} \mathrm{NaCl}$. Similar results were obtained with the C-terminal peptides except that there was greater loss of activity at $300 \mathrm{mM} \mathrm{NaCl}$. Human $\beta$-defensin- 1 antibacterial activity was more salt-sensitive than that of HE2 peptides, losing much of its activity at $\mathrm{NaCl}$ concentrations as low as $50 \mathrm{mM}$. When compared to HE2 C-terminal peptides, the full-length HE2 proteins retained somewhat greater antibacterial activity at $300 \mathrm{mM}$ salt concentration.

\section{Outer-membrane permeabilization}

The ability of HE2 proteins and their C-terminal peptides to permeabilize the outer membrane of $E$. coli was tested using NPN dye which fluoresces weakly in an aqueous environment, but strongly in the hydrophobic interior of cell membranes. Upon destabilization of the outer bacterial membrane by antimicrobial peptides, the dye enters the damaged membrane where it emits stronger fluorescence [49]. Incubation of bacteria with $\operatorname{HE} 2 \alpha$, $\mathrm{HE} 2 \beta 1$, and HE2 $\beta 2$ proteins as well as with $\mathrm{HE} 2 \alpha$ and $\mathrm{HE} \beta 2$ $\mathrm{C}$-terminal peptides resulted in a rapid dose-dependent increase in fluorescence within 3 min (Figures 7(A) and 7B). However, $\mathrm{HE} 2 \beta 1$ peptide resulted in a weak increase in fluorescence (Figure 7B). In contrast, the control LCN6 caused no change in the fluorescence. The right-hand panel in Figure 7(A) shows the time course of outer membrane permeabilization. HE2 proteins without the His tag had similar outer-membrane-permeabilizing activities when compared to their His-tagged counterparts. Exposure to the reduced and alkylated HE2 proteins and peptides resulted in no change in fluorescence, indicating that without the structural integrity conferred by disulphide bonds, the HE2 isoforms were unable to disrupt the bacterial outer membranes (Figure 7C).
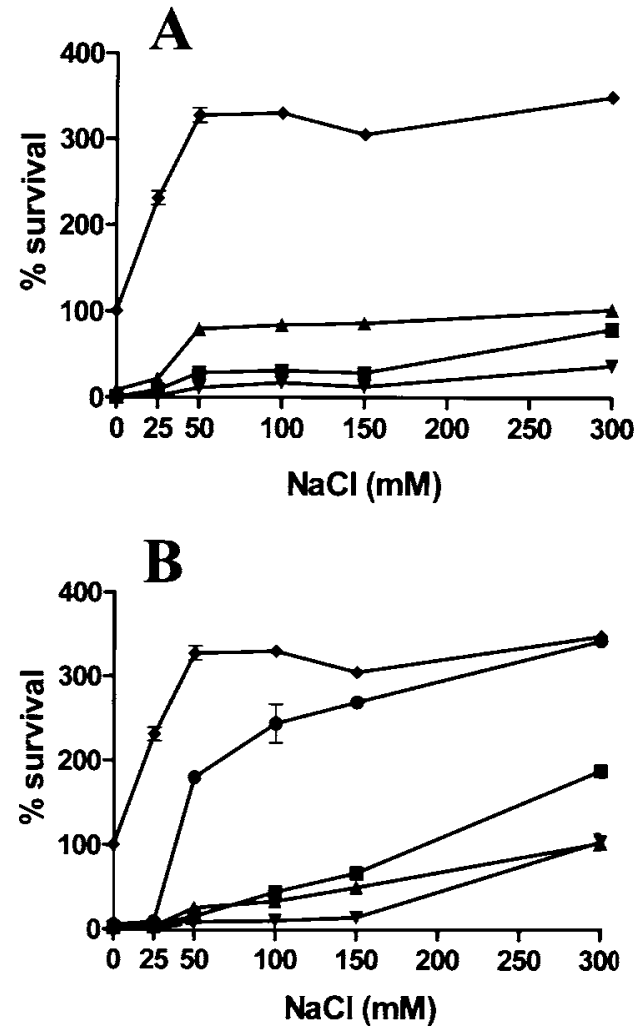

Figure 6 Effect of $\mathrm{NaCl}$ on the antibacterial activity of $\mathrm{HE} 2 \alpha, \beta 1$ and $\beta 2$ proteins and peptides

E. coli were incubated for $2 \mathrm{~h}$ with $25 \mu \mathrm{g} / \mathrm{ml}$ protein or peptide in $10 \mathrm{mM}$ sodium phosphate buffer ( $\mathrm{pH}$ 7.4) containing the indicated concentrations of $\mathrm{NaCl}$. (A) Effect of $\mathrm{NaCl}$ on the antibacterial activity of $\mathrm{HE} 2 \alpha, \beta 1$ and $\beta 2$ proteins. $\mathrm{NaCl}$ alone $(\bullet), \mathrm{HE} 2 \alpha(\boldsymbol{\square}), \mathrm{HE} 2 \beta 1(\boldsymbol{\Delta})$ and $\mathrm{HE} 2 \beta 2(\boldsymbol{\nabla})$. (B) Effect of $\mathrm{NaCl}$ on the antibacterial activity of $\mathrm{HE} 2 \alpha, \beta 1$ and $\beta 2$ peptides. $\mathrm{NaCl}$ alone $(\bullet)$, HE2 $\alpha$ peptide $(\boldsymbol{\square})$, HE2 $\beta 1$ peptide $(\boldsymbol{\Delta})$, HE2 $\beta 2$ peptide $(\boldsymbol{\nabla})$, and human $\beta$-defensin-1 (०).

\section{Inner-membrane permeabilization}

The cytoplasmic inner-membrane-permeabilization capacity of the HE2 family of epididymal proteins and peptides was investigated further using diSC3-5 dye that distributes itself between the cell interior and the medium according to the membrane potential. The dye accumulates in self-quenching aggregates inside the cell, allowing uptake to be measured as decreasing fluorescence. In our experiments, fluorescence declined to $20 \%$ of original levels in $10-15$ min and remained stable until HE2 proteins or peptides were added (results not shown). Addition of peptides resulted in the release of dye and a rapid increase in fluorescence (Figures $8 \mathrm{~A}$ and $8 \mathrm{~B}$ ). Increased fluorescence was detectable within $2 \mathrm{~min}$ and the dye was maximally released within 5 min after adding HE2 protein or peptide (Figure $8 \mathrm{~A}$, right-hand panel). His tag removal from HE2 proteins did not affect their inner-membrane-permeabilizing abilities. Reduced and alkylated HE2 proteins and peptides failed to damage the inner membrane (Figure $8 \mathrm{C}$ ).

Human $\beta$-defensin-1 also caused both outer- and innermembrane permeabilization. However it required longer incubation time periods with $E$. coli than did the HE2 proteins and peptides. As seen in Figure 9(A) and 9(B), HE2 $\beta 2$ peptide caused dose-dependent disruption of the outer and inner membranes within $1-5 \mathrm{~min}$, whereas human $\beta$-defensin- 1 required 60 150 min to achieve the same effects. 

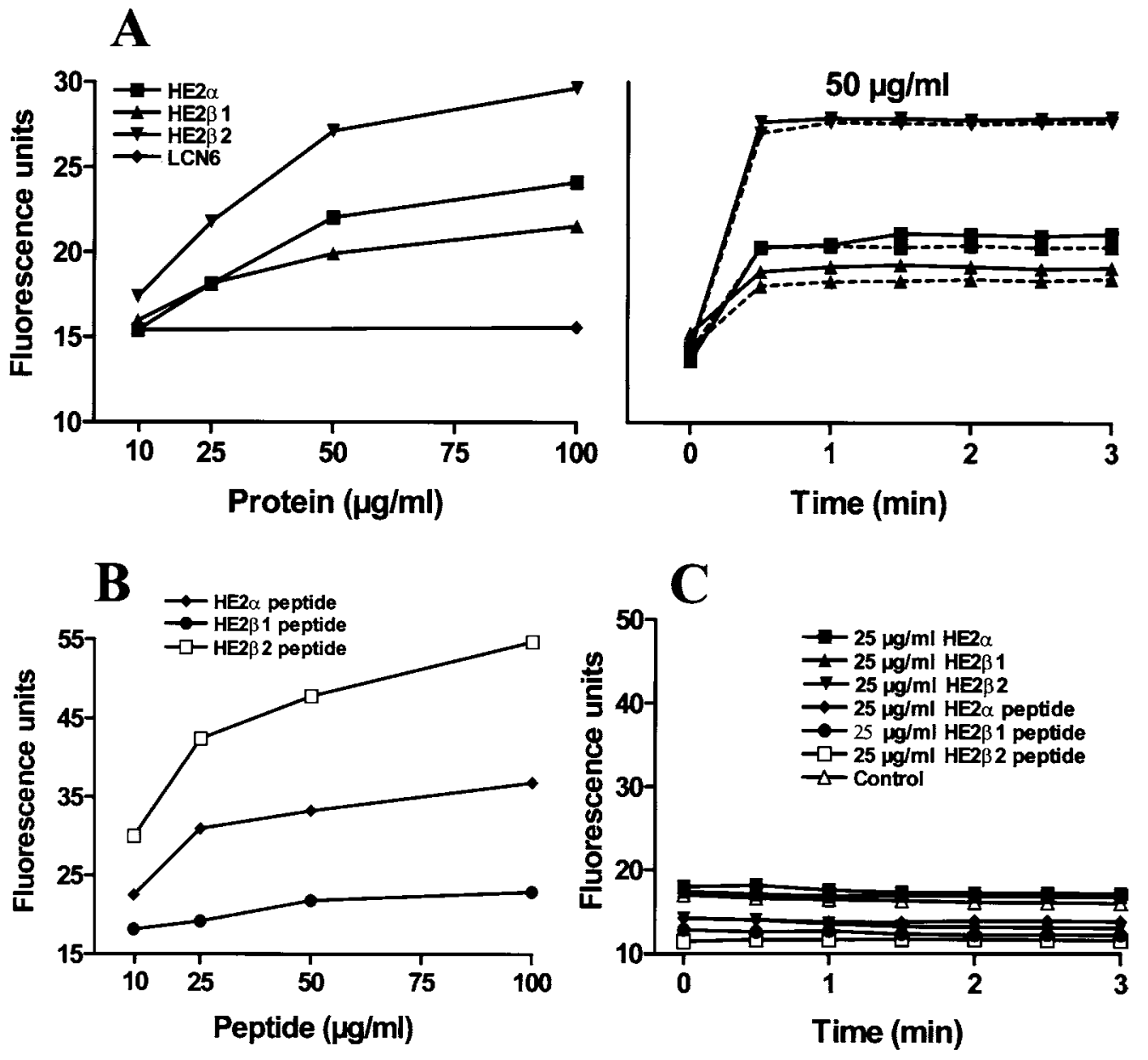

Figure 7 Outer-membrane permeabilization mediated by HE2 proteins and their C-terminal peptides as assessed by NPN uptake

(A) Outer-membrane permeabilization by HE2 proteins. Left-hand panel: concentration-dependent E. coli outer-membrane permeabilization mediated by HE2 proteins and LCN6 at 3 min. HE2 $\alpha$ ( $\mathbf{\square})$, HE2 $\beta 1(\boldsymbol{\Delta}), \mathrm{HE} 2 \beta 2(\boldsymbol{\nabla})$, LCN6 $(\bullet)$. Right-hand panel: time course of outer-membrane permeabilization at a concentration of $50 \mu \mathrm{g} / \mathrm{ml} \mathrm{HE2} \mathrm{proteins}$ with (solid line) and without (dashed line) His tag. (B) Concentration dependence of outer-membrane permeabilization mediated by HE2 C-terminal peptides at 3 min. HE2 $\alpha$ peptide $(\bullet)$, HE2 $\beta 1$ peptide $(\bullet)$, HE2 $\beta 2$ peptide ( $\square$ ). (C) Outer-membrane permeabilization by disulphide-bond reduced and alkylated HE2 proteins and peptides. HE2 $\alpha(\boldsymbol{\square})$, HE2 $\beta 1(\mathbf{\Delta})$, HE2 $\beta 2(\boldsymbol{\nabla})$, HE2 $\alpha$ peptide $(\bullet)$, HE2 $\beta 1$ peptide $(\boldsymbol{\bullet})$, HE2 $\beta 2$ peptide ( $\square)$, and control $(\triangle$, indicating that sodium phosphate buffer without protein was treated in the same manner as for alkylating the proteins, and dialysed to determine whether residual BME and iodoacetamide affected the release of dye in the assays).

\section{Haemolysis}

An erythrocyte assay was used to test the sensitivity of eukaryotic membranes to attack by $\mathrm{HE} 2 \alpha$, HE2 $\beta 1$, and HE2 $\beta 2$. No haemolysis was detected after $1 \mathrm{~h}$ exposure of rat erythrocytes to HE2 proteins or peptides even at a concentration of $100 \mu \mathrm{g} / \mathrm{ml}$ (results not shown). This result suggests that eukaryotic cell membranes are not as sensitive as E. coli membranes to disruption mediated by HE2 proteins and peptides. Like the erythrocytes, the neutral membranes of the epithelial cells lining the epididymis and the sperm are probably resistant to the destructive effects of HE2 proteins that are secreted into the epididymis lumen.

\section{DISCUSSION}

Sperm released from the seminiferous tubules of the testis acquire fertilizing ability as they pass through the epididymis. Several epididymis-specific proteins belonging to different families have been identified in recent years, however, the functions of most of these proteins are not yet known. Earlier work in our laboratory $[14,23,50,51]$ and others [7] identified human epididymal proteins including the splice variant HE2 gene products $(\mathrm{HE} 2 \alpha, \mathrm{HE} 2 \beta 1$ and HE2 $\beta 2$ ) and demonstrated their presence on ejaculated sperm. These proteins are expressed in the efferent ducts and initial segment of epididymis [23] and are available to interact with sperm as they leave the testis. Acquisition of fertilizing ability in the epididymis may be dependent on sperm-bound HE2 proteins. The structural features of HE2 proteins that cause disruption of bacterial membranes may alter the sperm plasma membrane in a manner that promotes sperm maturation rather than membrane destruction. The antibacterial activity displayed by HE2 proteins and peptides may be attributed to their cationic nature and similarity to $\beta$-defensins. Whether HE2 proteins retain their antibacterial capacity while bound to sperm and whether the C-terminal peptide is released from sperm in the male or female tracts to interact with bacterial membranes remain to be determined.

In the presence of HE2 proteins, the outer E. coli membrane was disrupted within $30 \mathrm{~s}$ and the inner membrane within $2 \mathrm{~min}$. Bacterial cell death was effected after a 5 min exposure to HE2 proteins. HE2 proteins killed bacteria after a shorter exposure than human $\beta$-defensin-1, which required $1 \mathrm{~h}$ to disrupt the outer membrane and $2 \mathrm{~h}$ for disruption of the inner membrane. Membrane disruption was shown previously for indolicidin 

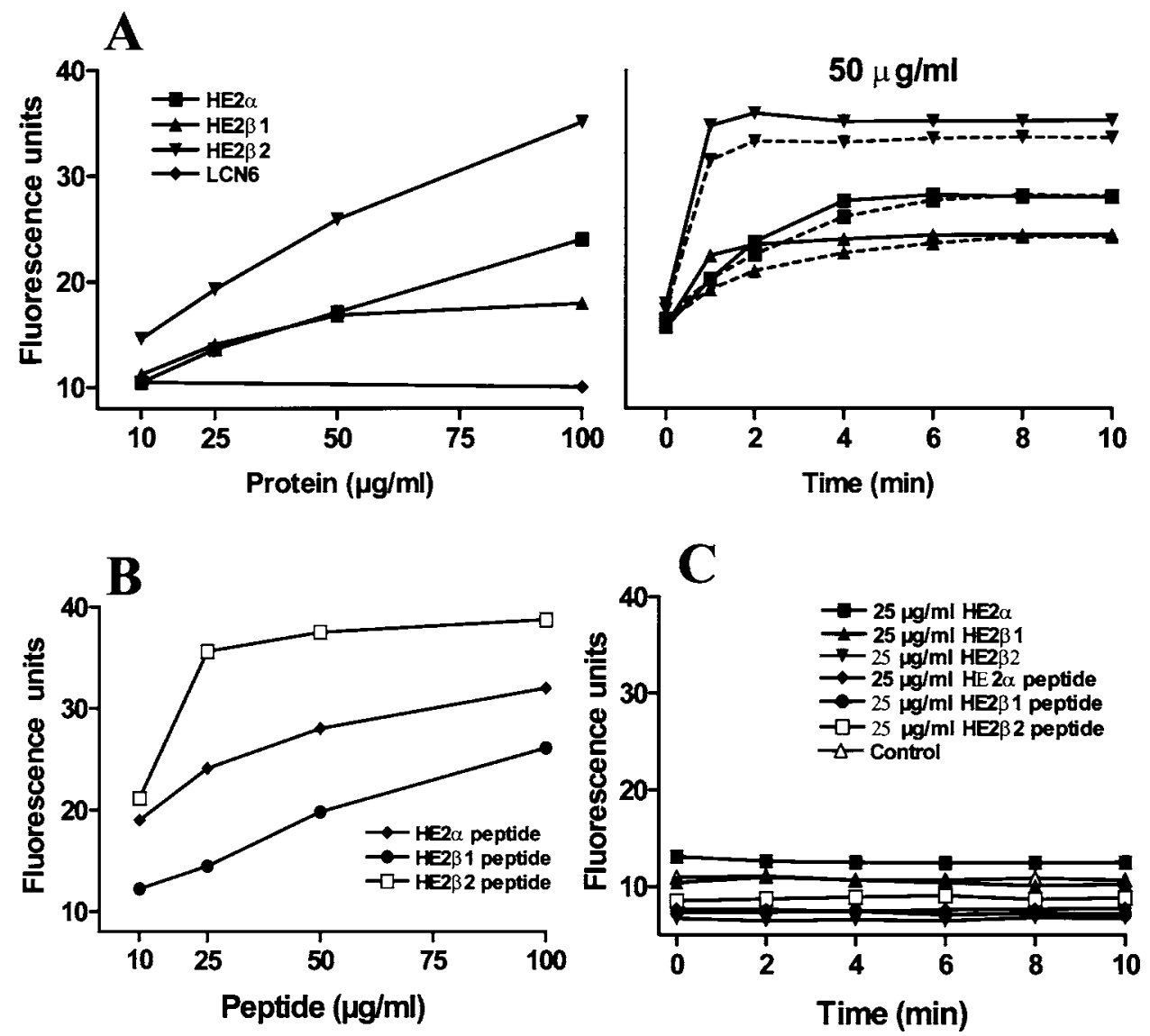

Figure 8 Inner-membrane permeabilization mediated by HE2 proteins and peptides as assessed by diSC3-5 assay

The specified concentration of the native or denatured protein or peptide was added to E. coli and florescence was monitored. (A) Inner-membrane permeabilization by HE2 proteins and LCN6. Left-hand panel: concentration dependent $E$. coli inner-membrane permeabilization by HE2 proteins at 10 min. HE2 $\alpha(\boldsymbol{\square})$, HE2 $\beta 1(\boldsymbol{\Delta})$, HE2 $\beta 2$ ( $\mathbf{\nabla})$, and LCN6 ( $\bullet$ ). Right-hand panel: time dependence of inner-membrane permeabilization by $50 \mu \mathrm{g} / \mathrm{ml}$ HE2 proteins with (solid line) and without (dashed line) His tag. (B) Concentration dependence of inner-membrane permeabilization mediated by HE2 C-terminal peptides. HE2 $\alpha$ peptide $(\bullet)$, HE2 $\beta 1$ peptide $(\mathbf{O})$, HE2 $\beta 2$ peptide $(\square)$. (C) Inner-membrane permeabilization by disulphide-bond reduced and alkylated HE2 proteins and peptides. HE2 $\alpha(\boldsymbol{\square}), \mathrm{HE} 2 \beta 1(\boldsymbol{\Delta})$, HE2 $\beta 2(\boldsymbol{\nabla}), \mathrm{HE} 2 \alpha$ peptide $(\bullet), \mathrm{HE} 2 \beta 1$ peptide $(\boldsymbol{\bullet})$, HE2 $\beta 2$ peptide $(\square)$, and control $(\triangle$, indicates sodium phosphate buffer without protein was treated in the same manner as for alkylating the proteins and dialysed to determine whether residual BME and iodoacetamide affected the release of dye in the assays).

[52,53], bactenectin [54], plant defensins [55] and peptides belonging to different classes [56]. Structural changes in the E. coli and Staphylococcus aureus outer membranes were observed when exposed to high concentrations of $\alpha$-defensins $[57,35]$. The loss of microbial viability brought about by antimicrobial peptides has been attributed to one or more of the following events: (1) formation of pores that cause cellular contents to leak [58], (2) interaction with critical factors inside the cell [59], (3) depolarization of the bacterial membrane [60], (4) changes in the distribution of membrane components [61], and (5) activation of cell-wall-degrading enzymes such as hydrolases [62]. Whether the loss of bacterial viability is due solely to membrane permeabilization, or whether HE2 proteins also interact with specific targets inside the bacteria is yet to be determined.

HE2 epididymal proteins contain varying numbers of cysteine residues, which are assumed to form intramolecular disulphide bonds. Membrane disruption and bacterial-killing activities of these proteins and peptides were abolished by reduction and alkylation of the disulphide bonds indicating the dependence of these activities on tertiary structure. Similarly, disulphide bond reduction cancelled the channel-forming activities of insect defensins [63] and protegrins [64] and the antibacterial activities of several other proteins [65-68]. It has been suggested that the disulphide bridges position positively charged and hydrophobic amino acids in clusters, effective in binding bacteria [69].

Antibacterial activities of HE2 proteins were clearly less inhibited by $\mathrm{NaCl}$ than was the activity of human $\beta$-defensin1. Salt tolerance was demonstrated for the antimicrobial activity of several cathelicidin-derived peptides [6], and other peptides [70-73], whereas $\beta$-defensins $[1,47,48]$ and horse cathelicidin peptides were salt sensitive [74]. The greater salt tolerance of HE2 proteins compared with human $\beta$-defensin- 1 suggests major differences in electrostatic interactions and perturbations that facilitate membrane disruption. Whether differences in the arrangement of basic and other amino acids lead to greater stability of HE2-bacterial interactions remains to be investigated. However, recent studies suggest that loss of peptide antimicrobial activity in higher salt concentrations may be related both to the degree of positive charge of the peptide and to the $\alpha$-helical content [40]. In this regard, the most potent peptide in this study, HE2 $\beta 2$ was the most salt-tolerant and is predicted [36] to contain a greater content of $\alpha$-helical structure than human $\beta$-defensin-1, HE $2 \alpha$ or $\beta 1$ peptides.

Antibacterial peptides that lyse bacterial membranes may also be toxic to eukaryotic cells [43], in which case they would be unsuitable as systemic drugs. However, in this study, the lack of haemolytic activity at the highest concentration of peptides used in 
Outer membrane permeabilization

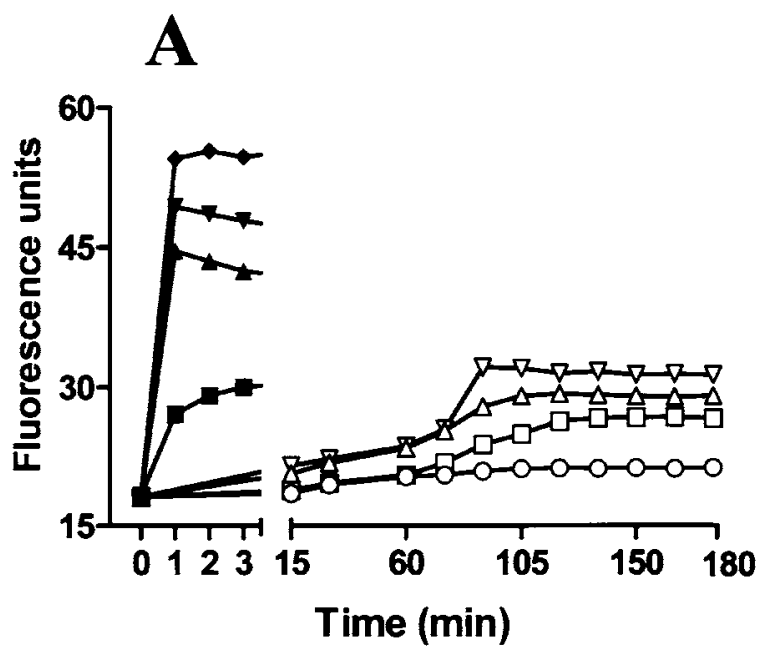

Inner membrane permeabilization

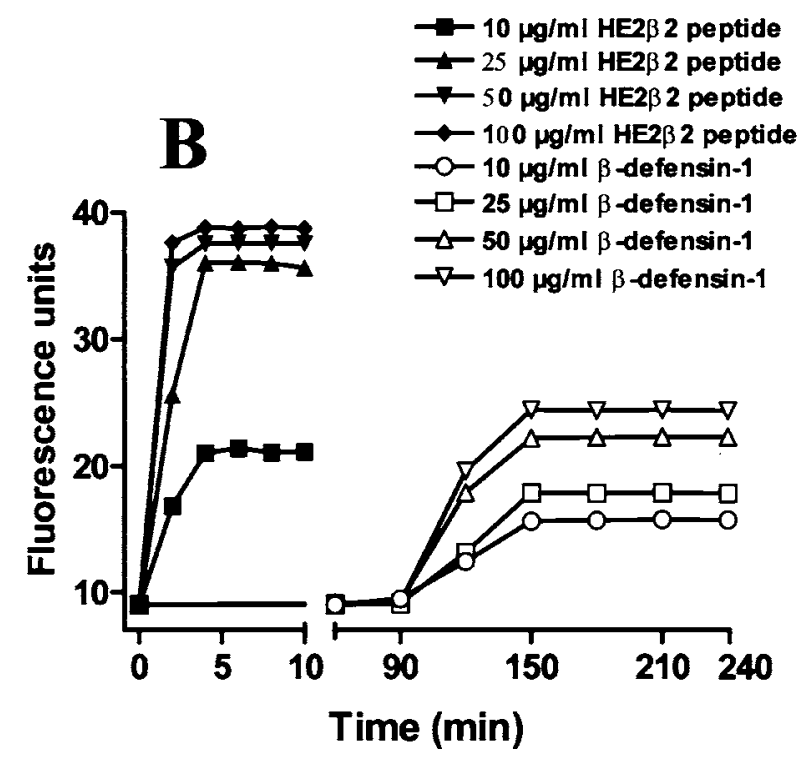

Figure 9 HE2 $\beta 2$ peptide mediates more rapid outer- and inner-membrane permeabilization than human $\beta$-defensin-1

(A) Outer-membrane permeabilization mediated by HE2 $\beta 2$ peptide and human $\beta$-defensin- 1 . (B) Inner-membrane permeabilization mediated by HE2 $\beta 2$ peptide and human $\beta$-defensin-1.

antibacterial assays indicated that the red-blood-cell membranes are not adversely affected. Further studies are required to know whether eukaryotic membranes are also resistant.

The mechanism of bacterial killing by HE2 peptides appears to begin with interaction with the outer bacterial membrane leading to outer and inner membrane disruption and cell death. Further experiments are needed to address whether interactions of HE2 proteins with specific membrane or intracellular factors contribute to bacterial destruction as reported for other antimicrobial proteins [59].

We thank Dr R.E.W. Hancock, Department of Microbiology and Immunology, University of British Columbia, Vancouver, British Columbia, Canada, for his valuable suggestions regarding the permeabilization assays. We also thank Dr Ashutosh Tripathy, Macromolecules Interaction Facility (MaClnFac), University of North Carolina, Chapel Hill, NC, U.S.A. and Dr Moo Choo, Department of Pharmacy, University of North Carolina,
Chapel Hill, NC, U.S.A. for permitting us to use the fluorescence spectrophotometer. This work was supported by the Consortium for Industrial Collaboration in Contraceptive Research Program of the Contraceptive Research and Development Program, Eastern Virginia Medical School, U.S.A. The views expressed by the authors do not necessarily reflect the views of Contraceptive Research and Development or Consortium for Industrial Collaboration in Contraceptive Research. This work is also supported by National Institute of Health Grants R37-HD04466, by National Institute of Child Health and Human development/NIH through cooperative agreement U54-HD35041 as part of the Specialized Cooperative Centers Program in Reproduction Research, and by the Fogarty International Center Training and research in Population and Health Grant D43TW/HD00627.

\section{REFERENCES}

1 Goldman, M. J., Anderson, G. M., Stolzenberg, E. D., Kari, U. P., Zasloff, M. and Wilson, J. M. (1997) Human $\beta$-defensin- 1 is a salt-sensitive antibiotic in lung that is inactivated in cystic fibrosis. Cell $\mathbf{8 8}, 553-560$

2 Nisapakultorn, K., Ross, K. F. and Herzberg, M.C. (2001) Calprotectin expression inhibits bacterial binding to mucosal epithelial cells. Infect. Immun. 69, 3692-3696

3 Nisapakultorn, K., Ross, K. F. and Herzberg, M. C. (2001) Calprotectin expression in vitro by oral epithelial cells confers resistance to infection by Porphyromonas gingivalis. Infect. Immun. 69, 4242-4247

4 Robinovitch, M. R., Ashley, R. L., Iversen, J. M., Vigoren, E. M., Oppenheim, F. G. and Lamkin, M. (2001) Parotid salivary basic proline-rich proteins inhibit HIV-1 infectivity. Oral Dis. 7, 86-93

5 Hall, S. H., Hamil, K. G. and French, F. S. (2002) Host defense proteins of the male reproductive tract. J. Androl. 23, 585-597

6 Travis, S. M., Anderson, N. N., Forsyth, W. R., Espiritu, C., Conway, B. D., Greenberg, E. P., McCray, P. B. Jr., Lehrer, R. I., Welsh, M. J. and Tack, B. F. (2000) Bactericidal activity of mammalian cathelicidin-derived peptides. Infect. Immun. 68, 2748-2755

7 Malm, J., Sørensen, O., Persson, T., Frohm-Nilsson, M., Johansson, B., Bjartell, A., Lilja, H., Ståhle-Bäckdahl, M., Borregaard, N. and Egesten, A. (2000) The human cationic antimicrobial protein (hCAP-18) is expressed in the epithelium of human epididymis, is present in seminal plasma at high concentrations and is attached to spermatozoa. Infect. Immun. 68, 4297-4302

8 Larrick, J. W., Hirata, M., Balint, R. F., Lee, J., Zhong, J. and Wright, S. C. (1995) Human CAP18: a novel antimicrobial lipopolysaccharide-binding protein. Infect. Immun. 63, 1291-1297

9 Reddy, E. S. and Bhargava, P. M. (1979) Seminalplasmin-an antimicrobial protein from bovine seminal plasma which acts in E. coli by specific inhibition of rRNA synthesis. Nature (London) 279, 725-728

10 Sitaram, N. and Nagaraj, R. (1990) A synthetic 13-residue peptide corresponding to the hydrophobic region of bovine seminalplasmin has antibacterial activity and also causes lysis of red blood cells. J Biol. Chem. 265, 10438-10442

11 Jin, Y. Z., Bannai, S., Dacheux, F., Dacheux, J. L. and Okamura, N. (1997) Direct evidence for the secretion of lactoferrin and its binding to sperm in the porcine epididymis. Mol. Reprod. Dev. 47, 490-496

12 Blankenvoorde, M. F., van't Hof, W., Walgreen-Weterings, E., van Steenbergen, T. J., Brand, H. S., Veerman, E. C. and Nieuw Amerongen, A. V. (1998) Cystatin and cystatin-derived peptides have antibacterial activity against the pathogen Porphyromonas gingivalis. Biol. Chem. 379, 1371-1375

13 Bjorck, L., Grubb, A. and Kjellen, L. (1990) Cystatin C, a human proteinase inhibitor, blocks replication of herpes simplex virus. J. Virol. 64, 941-943

14 Hamil, K. G., Liu, Q., Sivashanmugam, P., Yenugu, S., Soundararajan, R., Grossman, G. Richardson, R. T., Zhang Y.-L., O'Rand, M. G., Petrusz, P., French, F. S. and Hall, S. H. (2002) Cystatin 11: a new member of the cystatin type 2 family. Endocrinology 143, 2787-2786

15 Hiemstra, P. S., Maassen, R. J., Stolk, J., Heinzel-Wieland, R., Steffens, G. J. and Dijkman, J. H. (1996) Antibacterial activity of antileukoprotease. Infect. Immun. 64 4520-4524

16 McNeely, T. B., Dealy, M., Dripps, D. J., Orenstein, J. M., Eisenberg, S. P. and Wahl, S. M. (1995) Secretory leukocyte protease inhibitor: a human saliva protein exhibiting anti-human immunodeficiency virus 1 activity in vitro. J. Clin. Invest. 96, 456-464

17 Zhao, C., Wang, I. and Lehrer, R. I. (1996) Widespread expression of $\beta$-defensin hBD-1 in human secretory glands and epithelial cells. FEBS Lett. 396, 319-322

18 Garcia, J. R., Krause, A., Schulz, S., Rodriguez-Jimenez, F. J., Kluver, E., Adermann, K., Forssmann, U., Frimpong-Boateng, A., Bals, R. and Forssmann, W. G. (2001) Human $\beta$-defensin 4: a novel inducible peptide with a specific salt-sensitive spectrum of antimicrobial activity. FASEB J. 15, 1819-1821

19 Palladino, M. A., Mallonga, T. A. and Mishra, M. S. (2003) Messenger RNA (mRNA) expression for the antimicorbial peptides $\beta$-defensin- 1 and $\beta$-defensin- 2 in the male rat reproductive tract: $\beta$-defensin-1 mRNA in initial segment and caput epididymis is regulated by androgens and not bacterial lipopolysaccharides. Biol. Reprod. 68, 509-515 
20 Com, E., Bourgeon, F., Betrand, E., Ganz, T., Colleu, D., Jegou, B. and Pineau, C. (2003) Expression of antimicrobial defensins in the male reproductive tract of rats, mice, and humans. Biol. Reprod. 68, 95-104

21 Li, P., Chan, H. C., He, B., So, S. C., Chung, Y. W., Shang, Q., Zhang, Y. D. and Zhang, Y. L. (2001) An antimicrobial peptide gene found in the male reproductive system of rats. Science (Washington, D.C.) 291, 1783-1785

22 Osterhoff, C., Kirchhoff, C., Krull, N. and Ivell, R. (1994) Molecular cloning and characterization of novel human sperm antigen (HE2) specifically expressed in the proximal epididymis. Biol. Reprod. 50, 516-525

23 Hamil, K. G., Sivashanmugam, P., Richardson, R. T., Grossman, G., Ruben, S. M., Mohler, J. L., Petrusz, P., O'Rand, M. G., French, F. S. and Hall, S. H. (2000) HE2 $\beta$ and $\mathrm{HE} 2 \gamma$ : new members of an epididymis-specific family of androgen-regulated proteins in the human. Endocrinology 141, 1245-1253

24 Kirchhoff, C., Osterhoff, C., Habben, I., Ivell, R. and Kirchloff, C. (1990) Cloning and analysis of mRNAs expressed specifically in the human epididymis. Int. J. Androl. 13 155-167

25 Young, L. G., Frohlich, 0. and Gould, K. G. (1998) HE2/EP2, an androgen-dependent protein from the epididymis of the chimpanzee. J. Reprod. Fertil. Suppl. $\mathbf{5 3}$ 215-220

26 Frohlich, 0., Po, C., Murphy, T. and Young, L. G. (2000) Multiple promoter and splicing mRNA variants of the epididymis-specific gene EP2. J. Androl. 21, 421-430.

27 Frohlich, 0., Po, C. and Young, L. G. (2001) Organization of the human gene encoding the epididymis-specific EP2 protein variants and its relationship to defensin genes. Biol. Reprod. 64, 1072-1079

28 Schutte, B. C., Mitros, J. P., Bartlett, J. A., Walters, J. D., Jia, H. P., Welsh, M. J., Casavant, T. L. and McCray, P. B. Jr. (2002) Discovery of five conserved $\beta$-defensin gene clusters using a computational search strategy. Proc. Natl. Acad. Sci. U.S.A. 99 2129-2133

29 Horsten, H. H., Derr, P. and Kirchhoff, C. (2002) Novel antimicrobial peptide of human epididymal duct origin. Biol. Reprod. 67, 804-813

30 Bastian, A. and Schafer, H. (2001) Human alpha-defensin 1 (HNP-1) inhibits adenovira infection in vitro. Regul. Pept. 101, 157-161

31 Daher, K. A., Selsted, M. E. and Lehrer, R. I. (1986) Direct inactivation of viruses by human granulocyte defensins. J. Virol. 60, 1068-1074

32 Schibli, D. J., Hunter, H. N., Aseyev, V., Starner, T. D., Wiencek, J. M., McCray, P. B. Jr., Tack, B. F. and Vogel, H. J. (2002) The solution structures of the human $\beta$-defensins lead to a better understanding of the bactericidal activity of HBD3 against Staphylococcus aureus. J. Biol. Chem. 277, 8279-8289

33 Lehrer, R. I. and Ganz, T. (2002) Defensins of vertebrate animals. Curr. Opin. Immunol. 14, 96-102

34 Fujii, G., Selsted, M. E. and Eisenberg, D. (1993) Defensins promote fusion and lysis of negatively charged membranes. Protein Sci. 2, 1301-1312

35 Lehrer, R. I., Barton, A., Daher, K. A., Harwig, S. S., Ganz, T. and Selsted, M. E. (1989) Interaction of human defensins with Escherichia coli. Mechanism of bactericidal activity. J. Clin. Invest. 84, 553-561

36 Fischer, D. (2000) Hybrid fold recognition: combining sequence derived properties with evolutionary information. Pacif. Symp. Biocomp. 5, 116-127

37 Berman, H. M., Westbrook, J., Feng, Z., Gilliland, G., Bhat, T. N., Weissig, H., Shindyalov, I. N. and Bourne, P. E. (2000) The Protein Data Bank. Nucleic Acids Res. 28, 235-342

38 Christopher, J. A. (1998) SPOCK: The structural properties observation and calculation kit (Program Manual). College Station: The Center for Macromolecular Design, Texas A\&M University.

39 Reference deleted.

40 Nagaoka, I., Hirota, S., Yomogida, S., Ohwada, A. and Hirata, M. (2000) Synergistic actions of antibacterial neutrophil defensins and cathelicidins. Inflamm. Res. 49, 73-79

41 Loh, B., Grant, C. and Hancock, R. E. (1984) Use of the fluorescent probe $1-N$-phenylnaphthylamine to study the interactions of aminoglycoside antibiotics with the outer membrane of Pseudomonas aeruginosa. Antimicrob. Agents Chemother. $\mathbf{2 6}$ 546-551

42 Wu, M., Maier, E., Benz, R. and Hancock, R. E. (1999) Mechanism of interaction of different classes of cationic antimicrobial peptides with planar bilayers and with the cytoplasmic membrane of Escherichia coli. Biochemistry 38, 7235-7242

43 Fernandez-Lopez, S., Kim, H. S., Choi, E. C., Delgado, M., Granja, J. R., Khasanov, A., Kraehenbuehl, K., Long, G., Weinberger, D. A., Wilcoxen, K. M. and Ghadiri, M. R. (2001) Antibacterial agents based on the cyclic D,L-alpha-peptide architecture. Nature (London) 412, 452-455

44 Hoover, D. M., Rajashankar, K. R., Blumenthal, R., Puri, A., Oppenheim, J. J., Chertov, 0. and Lubkowski, J. (2000) The structure of human $\beta$-defensin-2 shows evidence of higher order oligomerization. J. Biol. Chem. 275, 32911-32918

45 Zasloff, M. (2002) Antimicrobial peptides of multicellular organisms. Nature (London) 415, 389-395
46 Mandal, M., Jagannadham, M. V. and Nagaraj, R. (2002) Antibacterial activities and conformations of bovine $\beta$-defensin BNBD-12 and analogs: structural and disulphide bridge requirements for activity. Peptides 23, 413-418

47 Singh, P. K., Jia, H. P., Wiles, K., Hesselberth, J., Liu, L., Conway, B. A., Greenberg, E. P., Valore, E. V., Welsh, M. J., Ganz, T., Tack, B. F. and McCray, P. B Jr. (1998) Production of $\beta$-defensins by human airway epithelia. Proc. Nat. Acad. Sci. U.S.A. 95, 14961-14966

48 Bals, R., Goldman, M. J. and Wilson, J. M. (1998) Mouse $\beta$-defensin 1 is a salt-sensitive antimicrobial peptide present in epithelia of the lung and urogenital tract. Infect. Immun. 66, 1225-1232

49 Fidai, S., Farmer, S. W. and Hancock, R. E. W. (1997) Interaction of cationic peptides with bacterial membranes. In antibacterial peptide protocols. (Shafer, W. M., ed.), pp. 187-204, Humana Press, Totowa, NJ

50 Richardson, R. T., Sivashanmugam, P., Hall, S. H., Hamil, K. G., Moore, P. A. Ruben, S. M., French, F. S. and O'Rand, M. (2001) Cloning and sequencing of human Eppin: a novel family of protease inhibitors expressed in the epididymis and testis. Gene 270, 93-102

51 Liu, Q., Hamil, K. G., Sivashanmugam, P., Grossman, G., Soundararajan, R., Rao, A. J., Richardson, R. T., Zhang, Y. L., O'Rand, M., Petrusz, P., French, F. S. and Hall, S. H. (2001) Primate epididymis-specific proteins: Characterization of ESC42, a novel protein containing a trefoil-like motif in monkey and human. Endocrinology 142. 4529-4539

52 Falla, T. J., Karunaratne, D. N. and Hancock, R. E. (1996) Mode of action of the antimicrobial peptide indolicidin. J. Biol. Chem. 271, 19298-19303

53 Subbalakshmi, C., Krishnakumari, V., Nagaraj, R. and Sitaram, N. (1996) Requirements for antibacterial and hemolytic activities in the bovine neutrophil derived 13-residue peptide indolicidin. FEBS Lett. 395, 48-52

54 Wu, M. and Hancock, R. E. (1999) Interaction of the cyclic antimicrobial cationic peptide bactenecin with the outer and cytoplasmic membrane. J. Biol. Chem. 274, 29-35

55 Thevissen, K., Terras, F. R. F. and Broekaert, W. F. (1999) Permeabilization of fungal membranes by plant defensins inhibits fungal growth. Appl. Environ. Microbiol. 65, 5451-5458

56 Friedrich, C. L., Moyles, D., Beveridge, T. J. and Hancock, R. E. (2000) Antibacterial action of structurally diverse cationic peptides on Gram-positive bacteria. Antimicrob. Agents Chemother. 44, 2086-2092

57 Shimoda, M., Ohki, K., Shimamoto, Y. and Kohashi, 0. (1995) Morphology of defensin-treated Staphylococcus aureus. Infect. Immun. 63, 2886-2891

58 Yang, L., Weiss, T. M., Lehrer, R. I. and Huang, H. W. (2000) Crystallization of antimicrobial pores in membranes: magainin and protegrin. Biophys. J. 79, 2002-2009

59 Otvos, L. Jr., Rogers, M. E., Consolvo, P. J., Condie, B. A., Lovas, S., Bulet, P. and Blaszczyk-Thurin, M. (2000) Interaction between heat-shock proteins and antimicrobial peptides. Biochemistry 39, 14150-14159

60 Westerhoff, H. V., Juretic, D., Hendler, R. W. and Zasloff, M. (1989) Magainins and the disruption of membrane-linked free-energy transduction. Proc. Natl. Acad. Sci. U.S.A. 86 6597-6601

61 Matsuzaki, K. (1999) Why and how are peptide-lipid interactions utilized for self-defense? Magainins and tachyplesins as archetypes. Biochim. Biophys. Acta 1462, 1-10

62 Bierbaum, G. and Sahl, H. G. (1985) Induction of autolysis of staphylococci by the basic peptide antibiotics Pep 5 and nisin and their influence on the activity of autolytic enzymes. Arch. Microbiol. 141, 249-254

63 Cociancich, S., Bulet, P., Hetru, C. and Hoffmann, J. A. (1994) The inducible antibacterial peptides of insects. Parasitol. Today 10, 132-139

64 Mangoni, M. E., Aumelas, A., Charnet, P., Roumestand, C., Chiche, L., Despaux, E., Grassy, G., Calas, B. and Chavanieu, A. (1996) Change in membrane permeability induced by protegrin 1: implication of disulphide bridges for pore formation. FEBS Lett. 383, 93-98

65 Kuzuhara, T., Nakajima, Y., Matsuyama, K. and Natori, S. (1990) Determination of the disulfide array in sapecin, an antibacterial peptide of Sarcophaga peregrina (flesh fly). J. Biochem. (Tokyo) 107, 514-518

66 Park, J. M., Jung, J. E. and Lee, B. J. (1994) Antimicrobial peptides from the skin of a Korean frog, Rana rugosa. Biochem. Biophys. Res. Commun. 205, 948-954

67 Raj, P. A., Karunakaran, T. and Sukumaran, D. K. (1999) Synthesis, microbicidal activity, and solution structure of the dodecapeptide from bovine neutrophils. Biopolymers $\mathbf{5 3}$ 281-292

68 Matsuzaki, K., Nakayama, M., Fukui, M., Otaka, A., Funakoshi, S., Fujii, N., Bessho, K. and Miyajima, K. (1993) Role of disulfide linkages in tachyplesin-lipid interactions. Biochemistry 32, 11704-11710

69 Yu, Q., Lehrer, R. I. and Tam, J. P. (2000) Engineered salt-insensitive alpha-defensins with end-to-end circularized structures. J. Biol. Chem. 275, 3943-3949

70 Shin, S. Y., Yang, S. T., Park, E. J., Eom, S. H., Song, W. K., Kim, Y., Hahm, K. S. and Kim, J. I. (2002) Salt resistance and synergistic effect with vancomycin of $\alpha$-helical antimicrobial peptide p18. Biochem. Biophys. Res. Commun 290, 558-562 
71 Choi, C. S., Lee, I. H., Kim, E. Kim, S. I. and Kim, H. R. (2000) Antibacterial properties and partial CDNA sequences of cecropin-like antibacterial peptides from the common cutworm, Spodoptera litura. Comp. Biochem. Physiol. C Toxicol. Pharmacol. 125, 287-297

72 Friedrich, C., Scott, M. G., Karunaratne, N., Yan, H. and Hancock, R. E. (1999) Salt-resistant $\alpha$-helical cationic antimicrobial peptides. Antimicrob. Agents Chemother. 43, 1542-1548

Received 7 February 2003/6 March 2003; accepted 11 March 2003

Published as BJ Immediate Publication 11 March 2003, DOI 10.1042/BJ20030225
73 Lauth, X., Shike, H., Burns, J. C., Westerman, M. E., Ostland, V. E., Carlberg, J. M., Van Olst, J. C., Nizet, V., Taylor, S. W., Shimizu, C. and Bulet, P. (2002) Discovery and characterization of two isoforms of moronecidin, a novel antimicrobial peptide from hybrid striped bass. J. Biol. Chem. 277, 5030-5039

74 Skerlavaj, B., Scocchi, M., Gennaro, R., Risso, A. and Zanetti, M. (2001) Structural and functional analysis of horse cathelicidin peptides. Antimicrob. Agents Chemother. $\mathbf{4 5}$, 715-722 
